\title{
Maternal and neonatal factors related to prematurity*
}

\author{
Fatores maternos e neonatais relacionados à prematuridade \\ Factores maternos y neonatales relacionados con la prematuridad
}

\author{
Laura Leismann de Oliveira ${ }^{1}$, Annelise de Carvalho Gonçalves ${ }^{2}$, Juvenal Soares Dias da Costa ${ }^{3,4}$, \\ Ana Lucia de Lourenzi Bonilha
}

\section{How to cite this article:}

Oliveira LL, Gonçalves AC, Costa JSD, Bonilha ALL. Maternal and neonatal factors related to prematurity. Rev Esc Enferm USP. 2016;50(3):382-389. DOI: http:// dx.doi.org/10.1590/S0080-623420160000400002

\footnotetext{
* Extracted from the thesis "Fatores maternos e neonatais relacionados à prematuridade", Programa de Pós-Graduação em Enfermagem, Universidade Federal do Rio Grande do Sul, 2015.

${ }^{1}$ Universidade Federal do Rio Grande do Sul, Hospital de Clínicas de Porto Alegre, Porto Alegre, RS, Brazil.

${ }^{2}$ Universidade Federal do Rio Grande do Sul, Escola de Enfermagem, Porto Alegre, RS, Brazil.

${ }^{3}$ Universidade do Vale do Rio dos Sinos, Programa de Pós-Graduação em Saúde Coletiva, São Leopoldo, RS, Brazil.

${ }^{4}$ Universidade Federal de Pelotas, Faculdade de Medicina, Departamento de Medicina Social, Pelotas, RS, Brazil.
}

\begin{abstract}
Objective: To identify maternal and neonatal factors associated with prematurity in the municipality of Porto Alegre. Method: This was a population-based case-control study. The cases were newborns under 37 weeks of gestation and the controls were newborns over 37 weeks. The data came from the records of 19,457 births in the city of Porto Alegre in the year 2012 from the Information System on Live Births of the Municipal Health Department. The analysis was carried out and adjusted by a Logistic Regression according to a hierarchical model. The variables studied were allocated into three hierarchy levels: sociodemographic variables; reproductive history; and gestational and birth factors. Results: There were 767 cases allocated and 1,534 controls in a design of a case for two controls (1:2) by simple randomization. In the final model, a statistically significant association was found for prematurity for the following variables: mother's age under 19 years old $(\mathrm{OR}=1.32$; CI 95\%: 1.02-1.71) or over 34 years old $(\mathrm{OR}=1.39$; CI 95\%: 1.12-1.72); inadequate maternal schooling for age ( $\mathrm{OR}=2.11$; CI 95\%: 1.22-3.65); multiple pregnancies (OR=1.14; CI 95\%: 1.01-1.29); C-section ( $\mathrm{OR}=1.15$; CI 95\%: 1.03-1.29); birth weights under 2,500g (OR=4.04; CI 95\%: 3.64-4.49); Apgar score at five minutes between zero and three (OR=1.47; CI 95\%: 1.12-1.91); and inadequate prenatal care $(\mathrm{OR}=1.18$; CI 95\%:1.02-1.36). Conclusion: The present study showed the most immediate consequence of prematurity for newborns by evidencing its association with worse Apgar scores and low birth weight. The following factors were also shown as possible more distal determinants of prematurity: mother's age; inadequate maternal education; multiple gestation; inadequate prenatal care; and $\mathrm{C}$-section.
\end{abstract}

\section{DESCRIPTORS}

Premature Birth; Risk Factors; Maternal-Child Nursing; Prenatal Care; Case-Control Studies.
Corresponding author:

Laura Leismann de Oliveira

Rua São Manoel, 963 - Sala 205 - Rio Branco

CEP 90620-110 - Porto Alegre, RS, Brazil

laura.|@terra.com.br
Received: 11/11/2015

Approved: 05/14/2016 


\section{INTRODUCTION}

Technological advances have provided better conditions of care and survival for children born prematurely, but the causes of these births are still little known ${ }^{(1)}$. Premature or preterm births are considered to be those before 37 weeks of gestation ${ }^{(2)}$. In global proportions, one out of every ten births was premature in the year of 2010 with an estimate of 15 million births. This represents a rate of $11.1 \%$ of the births, with one million deaths as a direct result of premature birth ${ }^{(2)}$.

The World Health Organization (WHO) considers prematurity as a global problem, especially because of its relationship with neonatal mortality. Brazil is among the ten countries with the highest rates, which are responsible for $60 \%$ of premature births in the world ${ }^{(2)}$. According to $\mathrm{WHO}$, in 2008 the main cause of death of children under five years of life was premature birth ${ }^{(3)}$. In Brazil, neonatal mortality is currently responsible for almost $70 \%$ of deaths in the first year of life, and appropriate care for newborns has been one of the challenges to reducing infant mortality indexes ${ }^{(4)}$.

In the year 2012, the rate of prematurity reached $12.1 \%$ in the state of Rio Grande do Sul ${ }^{(5)}$, while the national rate was $11.8 \%$. A cohort study conducted in the city of PelotasRS identified that this rate increased significantly in the region, from $6.3 \%$ in 1982 to $14.7 \%$ in $2004^{(6)}$. In the municipality of Porto Alegre, the rate of prematurity has been increasing in the last 10 years. In the year 2003, premature infants accounted for $10.8 \%$ of births, and by 2012 this rate had increased to $12.2 \%{ }^{(7)}$.

This investigation is justified when considering the magnitude of the occurrence of prematurity and the relevant increase in rates of premature births in Porto Alegre in the last 10 years. The article intends to expand the knowledge on the theme of perinatal health in the municipality of Porto Alegre, clarifying the perinatal factors associated with prematurity, with the aim of adapting gestational care in the detection and prevention of damage to health, and thus collaborate to reduce neonatal morbidity and mortality.

The objective of this article was to identify maternal and neonatal factors associated with prematurity in the municipality of Porto Alegre in the year 2012.

\section{METHOD}

The study's design was a population-based case-control study. The data came from the records of births in the city of Porto Alegre that were in the database of the Information System on Live Births (SINASC) for the year 2012, as supplied by the Municipal Health Department.

The parameters defined for calculating the sample size were as follows: detection of an odds ratio of 1.5, study power of $90 \%$, a significance level of 5\%, and the prevalence of $13 \%$ of exposure in controls with an estimated 767 cases and 1,534 controls in a design of a case for two controls (1:2).

The cases were newborns with a gestational age recorded as being less than 37 weeks of gestation, and the controls were newborns with a gestational age recorded as being equal to or greater than 37 weeks.
Records of newborns with a birth weight greater than or equal to $500 \mathrm{~g}$ and/or a gestational age greater than or equal to 22 weeks were included. Newborns without a record of some variable in the study were excluded.

In Porto Alegre, 19,457 children were born alive to city residents in the year 2012. Of the total population of live births, 25 children were excluded for lack of registering the gestational age, resulting in 19,432 . Of this population, 17,062 were term births, but 3,438 were excluded according to the exclusion criteria, thus totaling 13,624 births ready to be randomized to the group of controls. As for preterm infant births, these totaled 2,370, with 358 being excluded according to the exclusion criterion, thus totaling 2,012 records fit to be randomized to the group of cases. There were 767 cases and 1,534 controls allocated by simple randomization using the program PEPI version 4.0.

Prematurity was considered as a dependent variable. The independent variables included in the analysis were as follows:

Sociodemographic variables: mother's age ( $\leq 19$ years old; 20 to 34 years old; $\geq 35$ years old); living with a partner (yes; no); mother's level of education (adequate; inadequate); race/color (white; not white). The variable of the mother's level of education was categorized as adequate or inadequate for the mother's age depending on the last year of study completed by the woman. For this categorization, the classification was based on the one given by the Ministry of Education in which elementary education should be completed between ages 7 and 14, high school between ages 15 and 17, and college between ages 18 and $24^{(8)}$.

Reproductive history: number of previous live children (none; 1 to 2 children; 3 or more children); number of fetal losses/abortions (none; 1 to $2 ; 3$ or more); and number of previous pregnancies (none; 1 to $2 ; 3$ or more).

Gestational factors: type of pregnancy (single; multiple); prenatal care (adequate; inadequate); induction of labor (no; yes); fetal presentation (cephalic; pelvic/feet/breech); and mode of delivery (vaginal; cesarean section).

The prenatal variable was categorized according to the minimum number of prenatal doctor check-ups recommended for the gestational age of birth and the month when the prenatal visits began. Thus, the prenatal variable was considered as adequate when the woman had her first doctor visit before 16 weeks of gestation, associated with the number of doctor check-ups: one visit up to 25 weeks of gestation; two visits up until 31 weeks; three visits up until 36 weeks; four visits up until 37 weeks; and more than four visits when above 37 weeks of gestation.

Birth factors: sex of the newborn (female; male); Apgar score at five minutes after birth ( $\geq 7 ; 6$ to $4 ; 3$ to 0 ); birth weight $(\geq 2,500 \mathrm{~g} ;<2,500 \mathrm{~g})$; and detection of a congenital disorder (no; yes).

The Apgar score at one minute was not included in the analysis in order to control the effect of multicollinearity. We chose to include Apgar scores at five minutes because it is considered a more accurate marker of the neurological health prognosis of a newborn ${ }^{(8)}$. 
The variables were scaled by following the model for determining the outcome. The sociodemographic variables were placed in the first level because they determined the variables of the subjacent levels and the outcome. The intermediate level included the variables of reproductive history that in turn determined the variables of the more proximal level represented by the gestational and birth factors ${ }^{(10)}$.

In the unadjusted analysis of the data, the distribution of cases and controls was compared through a Pearson's chisquare together with the adjusted residual analysis, with a significance level of 0.05 . For the adjusted analysis, the hierarchical logistic regression was used to verify the results of odds ratios, $95 \%$ confidence intervals, and the statistical tests. The criterion for the variables entering the model was to present a p-value of $<0.20$ in the unadjusted analysis. During the adjustment, the variables were analyzed by level and were removed from the model if they lost significance. The coefficient of determination $\left(\mathrm{R}^{2}\right)$ of Cox and Snell was applied to evaluate the model's explanation percentage in relation to the outcome.

The study was evaluated and approved by the Research Ethics Committee at UFRGS under case no. 555,928/2014.

\section{RESULTS}

In 2012, of the 19,457 births that occurred in Porto Alegre, 2,370 of these births were classified as premature infants, which corresponds to a prevalence of $12.2 \%$ (CI 95\% 12.6-11.7).

In the unadjusted analysis, as for the reproductive variables, the cases of higher occurrence of prematurity were observed in the extreme age brackets ( $\leq 19$ years old and $\geq 35$ years old) and in mothers with an educational level considered as inadequate, with statistically significant differences. No differences were found between cases and controls with regard to living with a companion and race/ color. As for the variables related to reproductive health, no statistical differences were observed between cases and controls. However, higher frequencies of prematurity were found among women with multiple gestation, with inadequate prenatal care, who had induced deliveries, and among those who had a cesarean section mode of delivery. Among the variables that represented the birth conditions, higher frequencies of prematurity were observed in children with the worst Apgar scores at the fifth minute, those with congenital disorders, and those with a low birth weight, with statistically significant differences. No differences were observed between cases and controls in relation to the sex of the newborn (Table 1).

Table 1 - Distribution of the sample in relation to sociodemographic variables, of reproductive history, gestational factors, and birth factors - Porto Alegre, RS, Brazil, 2012.

\begin{tabular}{lrrr}
\hline Variable & Cases n (\%) & Controls n (\%) & p-value \\
\hline 1st level & & & \\
Mother's age & & & 0.002 \\
$\leq 19$ years old & $112(14.6)$ & $193(12.6)$ & \\
20 to 34 years old & $474(61.8)$ & $1,057(68.9)$ & \\
\hline
\end{tabular}

\begin{tabular}{|c|c|c|c|}
\hline Variable & Cases n (\%) & Controls n (\%) & p-value \\
\hline$\leq 35$ years old & $181(23.6)$ & $284(18.5)$ & \\
\hline Living with companion & & & 0.42 \\
\hline Yes & $365(47.6)$ & 759 (49.5) & \\
\hline No & $402(52.4)$ & $775(50.5)$ & \\
\hline Mother's education & & & 0.009 \\
\hline Adequate & $740(96.5)$ & $1,508(98.3)$ & \\
\hline Inadequate & $27(3.5)$ & $26(1.7)$ & \\
\hline Race/color & & & 0.06 \\
\hline White & $601(78.4)$ & $1,145(74.6)$ & \\
\hline Not white & $166(21.6)$ & $389(25.4)$ & \\
\hline \multicolumn{4}{|l|}{ 2nd level } \\
\hline Previous children & & & 0.13 \\
\hline None & $414(54.0)$ & 791 (51.6) & \\
\hline 1 to 2 children & $276(36.0)$ & $613(40.0)$ & \\
\hline 3 or more children & $77(10.0)$ & $130(8.5)$ & \\
\hline Fetal losses/abortions & & & 0.11 \\
\hline None & $613(80.0)$ & $1,249(81.4)$ & \\
\hline 1 to 2 & $143(18.6)$ & $276(18.0)$ & \\
\hline 3 or more & $11(1.4)$ & $9(0.6)$ & \\
\hline Previous vaginal births & & & 0.952 \\
\hline 0 & $526(68.6)$ & 1,043 (68.0) & \\
\hline 1 to 2 & $191(24.9)$ & $387(25.2)$ & \\
\hline 3 or more & $50(6.5)$ & $104(6.8)$ & \\
\hline Previous C-sections & & & 0.128 \\
\hline 0 & $611(79.7)$ & $1,213(19.1)$ & \\
\hline 1 to 2 & $142(18.5)$ & 307 (20.0) & \\
\hline 3 or more & $14(1.8)$ & $14(0.9)$ & \\
\hline Previous pregnancies & & & 0.26 \\
\hline 0 & $351(45.8)$ & $676(44.1)$ & \\
\hline 1 to 2 & 306 (39.9) & $663(43.2)$ & \\
\hline 3 or more & $110(14.3)$ & $195(12.7)$ & \\
\hline \multicolumn{4}{|l|}{ 3rd level } \\
\hline Type of pregnancy & & & $<0.001$ \\
\hline Single & $683(89.0)$ & $1,507(98.2)$ & \\
\hline Multiple & $84(11.0)$ & $27(1.8)$ & \\
\hline Prenatal care & & & 0.03 \\
\hline Adequate & $662(86.3)$ & $1,372(89.4)$ & \\
\hline Inadequate & 105 (13.7) & $162(10.6)$ & \\
\hline Induction of labor & & & $<0.001$ \\
\hline No & $572(74.6)$ & $1,030(67.1)$ & \\
\hline Yes & $195(25.4)$ & 504 (32.9) & \\
\hline Presentation & & & $<0.001$ \\
\hline Cephalic & $679(88.5)$ & $1,458(95.0)$ & \\
\hline Pelvic/feet/breech & $88(11.5)$ & $76(5.0)$ & \\
\hline Mode of delivery & & & $<0.001$ \\
\hline Vaginal & $294(38.3)$ & $748(48.8)$ & \\
\hline Cesarean section & $473(61.7)$ & $786(51.2)$ & \\
\hline
\end{tabular}




\begin{tabular}{lrrc}
\hline $\begin{array}{l}\text {...continuation } \\
\text { Variable }\end{array}$ & Cases n (\%) & Controls n (\%) & p-value \\
\hline Gender of the newborn & & & 0.35 \\
Female & $359(46.8)$ & $751(49.0)$ & \\
Male & $408(53.2)$ & $783(51.0)$ & \\
5th minute Apgar score & $733(95.5)$ & & \\
$\geq 7$ & & $1,523(99.3)$ & $<0.001$ \\
6 to 4 & $25(3.3)$ & $11(0.7)$ & \\
3 to 0 & $9(1.2)$ & $0(0.0)$ & \\
Birth weight & & & $<0.001$ \\
$\geq 2500 g$ & $376(49.0)$ & $1,479(96.4)$ & \\
$<2500 g$ & $391(51.0)$ & $55(3.6)$ & \\
Congenital disorders & & & 0.006 \\
No & $737(96.1)$ & $1,505(98.1)$ & \\
Yes & $30(3.9)$ & $29(1.9)$ & \\
\hline
\end{tabular}

In the logistic regression after adjustments among themselves, the sociodemographic variables of the distal level that remained associated with prematurity were the mother's age being under 19 years old $(\mathrm{OR}=1.32$; CI 95\%: 1.02-1.71) and over 35 years old $(\mathrm{OR}=1.39$; $\mathrm{CI} 95 \%$ : 1.12-1.72), and the mother's inadequate schooling for her age $(\mathrm{OR}=2.11$; CI 95\%: 1.22-3.65). The variables of the intermediate level, which represented the reproductive history, were not associated with prematurity after adjusting for the mother's age and for her level of education. The following factors remained associated with prematurity after an adjustment in the distal level for the mother's age and for her level of education: women with multiple pregnancies and with inadequate prenatal care; children born by cesarean section; those with an Apgar score at five minutes of three or less; and those with a low birth weight. It should be pointed out that the most elevated effect measures were observed among children with a low birth weight and those of mothers classified as having an inadequate level of education (Table 2).

The final model explains $28.5 \%$ of the factors associated with prematurity. This means that there are still other variables associated with prematurity but that the Statement of Live Birth (SLB) does not consider.

Table 2 - Logistic Regression of prematurity adjusted by the sociodemographic variables, of reproductive history, and of gestational and birth factors - Porto Alegre, RS, Brazil, 2012.

\begin{tabular}{lcccc}
\hline Variable & $\begin{array}{c}\text { Odds } \\
\text { ratio }\end{array}$ & Cl 95\% & p-value & $\begin{array}{c}\mathbf{R}^{2} \text { Cox } \\
\text { \& Snell }\end{array}$ \\
\hline 1st level & & & & $1 \%$ \\
Mother's age* & & & & \\
$\leq 19$ years old & 1.32 & $1.02-1.71$ & 0.03 & \\
20 to 34 years old & 1.0 & & & \\
$\leq 35$ years old & 1.39 & $1.12-1.72$ & 0.003 & \\
Race/Color & & & & \\
White & 1.21 & $0.98-1.49$ & 0.078 & \\
Not white & 1 & & & \\
\hline
\end{tabular}

continued... ...continuation

\begin{tabular}{lcccc}
\hline Variable & $\begin{array}{c}\text { Odds } \\
\text { ratio }\end{array}$ & Cl 95\% & p-value & $\begin{array}{c}\mathbf{R}^{2} \text { Cox } \\
\text { \& Snell }\end{array}$ \\
\hline $\begin{array}{l}\text { Mother's education* } \\
\text { Adequate }\end{array}$ & 1.0 & & & \\
Inadequate & 2.11 & $1.22-3.65$ & 0.008 & \\
\hline 2nd level & & & & $1.3 \%$ \\
Previous children** & & & & \\
None & 1.0 & & & \\
1 to 2 children & 0.89 & $0.71-1.11$ & 0.30 & \\
3 or more children & 0.96 & $0.67-1.38$ & 0.82 & \\
Fetal losses/abortions** & & & & \\
None & 1 & & & \\
1 to 2 & 1.05 & $0.83-1.32$ & 0.68 & \\
3 or more & 2.42 & $0.99-5.93$ & 0.05 &
\end{tabular}

\section{Previous C-sections**}

\begin{tabular}{lcccc} 
None & 1.0 & & & \\
1 to 2 & 0.97 & $0.74-1.26$ & 0.82 & \\
3 or more & 1.96 & $0.87-4.42$ & 0.11 & \\
\hline 3rd level & & & & $28.5 \%$
\end{tabular}

Type of pregnancy**

$\begin{array}{lccc}\text { Single } & 1.0 & & \\ \text { Multiple } & 1.14 & 1.01-1.29 & 0.04\end{array}$

Prenatal care**

Adequate

1.0

Inadequate

$1.18 \quad 1.02-1.36 \quad 0.03$

Induction of labor**

No

1.0

Yes

$1.03 \quad 0.91-1.17$

0.68

Presentation**

Cephalic

Pelvic/feet/breech

1.0

Mode of delivery**

Vaginal

1.0

Cesarean section

$1.15 \quad 1.03-1.29 \quad 0.02$

5th minute Apgar score**

$\geq 7$

6 to 4

1.0

$1.07 \quad 0.80-1.28 \quad 0.47$

3 to 0

$1.47 \quad 1.12-1.91 \quad 0.005$

Birth weight**

$\geq 2500 \mathrm{~g}$

1.0

$<2500 \mathrm{~g}$

$\begin{array}{lll}4.04 & 3.64-4.49 \quad 0.04\end{array}$

Congenital disorders**

No

1.0

Yes

$1.25 \quad 0.97-1.60 \quad 0.09$

* Variables adjusted among themselves.

** Variables adjusted for mother's age and educational level. 


\section{DISCUSSION}

In the statistical analysis, the following variables were significantly associated with prematurity: maternal age; educational level; type of pregnancy; mode of delivery; Apgar score at five minutes; birth weight; and inadequate prenatal care.

The mother's age exerts an influence on the occurrence of premature birth. Adolescent women (under the age of 20) and those with an advanced age (older than 34 years old) presented an association with premature delivery, corroborating to the existing literature ${ }^{(9-13)}$. A cross-sectional study conducted in Feira de Santana-BA showed that the risk of premature birth increased with the decrease in the mother's age, which can reach a relative risk of 10 times higher in women up to the age of 16 years old ${ }^{(14)}$. In another study, even in places with higher incomes, women over the age of 40 had 2.6 more premature deliveries out of 100 births than women between the age of 25 and 29 years old ${ }^{(12)}$. At the Teaching Hospital in Maranhão, prematurity occurred in a greater percentage among adolescents at $21.4 \%$, while it was $15.7 \%$ among adults ${ }^{(10)}$.

It is unclear whether the mother's age is an independent risk factor with a direct effect on prematurity, or if it acts indirectly, associated with confounding agents such as chronic diseases or sociodemographic factors. What is known is that the mother's advanced age is related to an increase in the prevalence of preexisting chronic diseases and of medical problems during pregnancy and delivery ${ }^{(11)}$.

In Porto Alegre, the number of women who have become pregnant at an advanced age had a small increase in the last five years of $1.8 \%$, from $16.1 \%$ in 2008 to $17.9 \%$ in $2012^{(7)}$. This fact can be a reflection of the development of the technology assisting reproduction in infertile women in recent years.

Women with an inadequate educational level for their age were associated with prematurity, which is in agreement with the existing literature ${ }^{(15-16)}$. These women are twice as likely to have a premature delivery. In a study performed in Quebec, Canada, prematurity rates decreased in accordance with increased schooling, reaching $7.9 \%$ in women with fewer than 11 years of study and $4.9 \%$ in women with over 17 years of education ${ }^{(15)}$. Another study found the adjusted risk for a premature birth at $92 \%$ higher in women with less education when compared with those with higher levels of education ${ }^{(16)}$. Education can be considered as a variable determined by socioeconomic conditions. In this way, this study showed that prematurity is also associated with worse living conditions, because the participants with inadequate education presented a higher frequency of outcome.

In this study, as well as in the literature, a multiple pregnancy (twins or triplets) presented an association with prematurity, keeping its association in the multivariate analysis ${ }^{(1,9,13,17-19)}$. A case-control study performed in Paraná indicated that births of multiple gestations presented 25 times more of a chance for premature birth ${ }^{(1)}$. A Brazilian multi-center study with 20 maternity hospitals that are a reference is obstetric demonstrated that a twin pregnancy increased by 15 times the chance of a premature birth ${ }^{(18)}$.
And in a cross-sectional study in Maringá, there is a 17 times higher chance of babies being born prematurely in multiple gestations ${ }^{(19)}$.

As for the mode of delivery, the cesarean section presented a higher proportion of premature births. Babies born by $\mathrm{C}$-section had a $15 \%$ higher chance of being premature. A study of trends in premature births in Pelotas, Rio Grande do Sul that followed three birth cohorts found a rate of cesarean section that increased from 28\% in 1982 to $45 \%$ in 2004 , with a concomitant increase in preterm births from $6.3 \%$ in 1982 to $14.7 \%$ in $2004^{(6)}$. This increase in preterm births can be explained in part by the ascending number of interruptions of pregnancy ${ }^{(6)}$.

It is important to be careful when analyzing premature births resulting from cesarean sections. It is worth pointing out that the risk of maintaining the pregnancy must be carefully balanced out with the risks of delivery associated with the risks of a premature birth ${ }^{(20)}$.It is worth remembering that preeclampsia is the most common cause for indicating a planned cesarean section ${ }^{(21)}$.

In this study, the Apgar score at five minutes of life from zero to three also presented a higher proportion in premature births, which is in agreement with the existing literature ${ }^{(8,22-23)}$. Among preterm infants, there is a higher incidence of low values of Apgar, considering that there are twice as many chances of this occurring in the first minute and 2.14 times more in the fifth minute. The prevalence of low Apgar scores is a relevant risk factor for morbidity and mortality among premature newborns ${ }^{(19)}$. An Apgar score between zero and three in the fifth minute of life was strongly associated with premature births in a Scottish study. According to this study, these premature babies presented 359 times more of a chance of neonatal death in the first week of life and more than 30 times for neonatal death up to 28 days of life ${ }^{(22)}$.

Low Apgar scores in premature newborns are observed even in the absence of indicators of fetal distress, and are due to physiological immaturity with a decrease of grimace and an inability to respond in an autonomous manner to cardiovascular and respiratory functions ${ }^{(23-24)}$.

In this study, low birth weight showed a strong association with premature births. The birth weight less than $2,500 \mathrm{~g}$ presented four times more chances to be associated with premature birth, being, therefore, a risk factor related to neonatal morbidity and mortality ${ }^{(19)}$. These data are in agreement with another study that followed three birth cohorts and showed that the proportion of preterm infants between babies of low birth weight had a striking increase from $45 \%$ in 1982 to $60 \%$ in 1993 and $67.3 \%$ in $2004^{(6)}$. A cross-sectional study conducted in Santa Maria showed that $78 \%$ of babies born with a low birth weight were born as preterm infants, which points to prematurity as the main factor responsible for low birth weight ${ }^{(25)}$. This relationship between the gestational age and birth weight seemed to be direct - the shorter the intrauterine development time the smaller were the sizes and weights of the newborns.

The data on births, such as type of pregnancy, birth weight, and Apgar score at five minutes were associated 
with a premature birth. These data are significant, as they express the conditions of neonatal births. If some of these conditions such as twins or low fetal weight gain are seen during pregnancy, it is necessary that more attention be taken during prenatal care in order that the pregnancy continues as close as possible to term. Perhaps these data of birth cannot avoid prematurity, but knowing the association of these with premature birth makes it possible to improve the care of these babies after birth.

The women classified as receiving inadequate prenatal care showed an $18 \%$ increase in the chance of having a premature birth. This finding agrees with those presented in the literature ${ }^{(1,10,13,19,26-28)}$. A study in Imperatriz, Maranhão concluded that if prenatal care is absent or inadequate, this would increase the chances of prematurity by five times ${ }^{(26)}$, which was also the conclusion of a cohort study carried out in Londrina ${ }^{(1)}$. Another cross-sectional study identified that, for women with fewer than four doctor visits, the chances increased by five times, while for those who had made between four and seven doctor visits the chances would increase by more than twice ${ }^{(19,27)}$. Vasconcelos et al., however, in a case-control study, found an odds ratio of four for women without complete prenatal care to have a premature delivery ${ }^{(28)}$. Therefore, an inversely proportional significant association was found between the number of doctor visits and premature delivery ${ }^{(27)}$.

In a study to assess the care system in order to reduce premature births and hospital stays of pregnant women with a history of premature delivery in the United States, an intervention group received home visits of obstetric nurses beyond the usual prenatal care. The results indicated that the intervention was beneficial: with each increase in the number of visits in the study, the probability of a term birth duplicated and significantly increased the gestational age at birth (1.2 gestational days), which was reflected in better birth conditions of the preterm babies ${ }^{(29)}$.

\section{CONCLUSION}

The increase in the prevalence of prematurity is an event that concerns health managers throughout the country and is in contrast with the increase of technological development in medical care and the reduction of infant mortality. Prematurity is a complex public health problem because it is a multifactorial issue that is interrelated and can vary in different populations.

Prenatal care has a fundamental role in lowering premature births. It is essential to identify a pregnant woman early on and to start prenatal care soon. This way the health professional will be able to identify the gestational risks with a preterm birth, the treatment of complications, and the referral for treatment in the case of greater complexities, if necessary. The present study showed the most immediate consequence of prematurity for newborns by evidencing its association with worse Apgar scores and low birth weight. The following factors were also shown as possible more distal determinants of prematurity: the mother's age, inadequate maternal education, multiple gestation, inadequate prenatal care, and $\mathrm{C}$-section.

It is believed that it is necessary to develop regional population studies due to the great diversity in the Brazilian population. Considering the significant part of prematurity in infant mortality, it is imperative that research with this theme continues to elucidate the causes of prematurity in order to help in planning preventive actions to combat this, consequently decreasing infant morbidity and mortality.

\section{RESUMO}

Objetivo: Identificar fatores maternos e neonatais associados à prematuridade no município de Porto Alegre. Método: Estudo do tipo caso-controle de base populacional. Os casos foram recém-nascidos com menos de 37 semanas de gestação, e os controles foram os recém-nascidos com 37 semanas ou mais. Os dados provieram dos registros de 19.457 nascimentos do município de Porto Alegre, no ano de 2012, no Sistema de Informações sobre Nascidos Vivos da Secretaria Municipal da Saúde. Foi realizada análise ajustada mediante Regressão Logística segundo modelo hierárquico. As variáveis estudadas foram alocadas em três níveis de hierarquia: variáveis sociodemográficas; história reprodutiva; fatores gestacionais e de nascimento. Resultados: Foram alocados 767 casos e 1.534 controles, em um desenho de um caso para dois controles (1:2), mediante randomização simples. No modelo final, foi encontrada associação estatisticamente significante para prematuridade para as seguintes variáveis: idade materna menor que 19 anos $(\mathrm{OR}=1,32 ; \mathrm{IC} 95 \%$ : 1,02 - 1,71) e maior que 34 anos (OR=1,39; IC 95\%: 1,12 - 1,72); escolaridade materna inadequada para a idade (OR=2,11; IC 95\%: 1,22 - 3,65); gravidez múltipla (OR=1,14; IC 95\%: 1,01 - 1,29); cesariana (OR=1,15; IC 95\%: 1,03 - 1,29); peso ao nascer menor a 2.500g $\left(\mathrm{OR}=4,04\right.$; IC 95\%: 3,64 - 4,49); Índice de Apgar no $5^{\circ}$ minuto de zero a três $(\mathrm{OR}=1,47 ; \mathrm{IC} 95 \%$ : $1,12-1,91)$ e pré-natal inadequado $(\mathrm{OR}=1,18$; IC 95\%: 1,02 - 1,36). Conclusão: $\mathrm{O}$ presente estudo evidenciou as consequências mais imediatas da prematuridade para os recém-nascidos ao revelar sua associação com piores escores de Apgar e baixo peso ao nascimento. Mostrou como possíveis determinantes mais distais de prematuridade: idade materna, educação materna inadequada, gestação múltipla, pré-natal inadequado e realização de cesariana.

\section{DESCRITORES}

Nascimento Prematuro; Fatores de Risco; Enfermagem Materno-Infantil; Cuidado Pré-Natal; Estudos de Casos e Controles.

\section{RESUMEN}

Objetivo: Identificar factores maternos y neonatales asociados con la prematuridad en el municipio de Porto Alegre. Método: Estudio del tipo caso control de base poblacional. Los casos fueron recién nacidos con menos de 37 semanas de gestación, y los controles fueron los recién nacidos con 37 semanas o más. Los datos provinieron de los registros de 19.457 nacimientos del municipio de Porto Alegre, en el año de 2012, en el Sistema de Informaciones acerca de Nacidos Vivos de la Secretaría Municipal de Salud. Se llevó a cabo el análisis ajustado mediante Regresión Logística según modelo jerárquico. Las variables estudiadas fueron ubicadas en tres niveles de jerarquía: variables sociodemográficas; historia reproductiva; factores gestacionales y de nacimiento. Resultados: Fueron ubicados 767 casos y 
1.534 controles, en un diseño de un caso para dos controles (1:2), mediante aleatorización simple. En el modelo final, fue encontrada asociación estadísticamente significativa para prematuridad para las siguientes variables: edad materna menor que 19 años $(\mathrm{OR}=1,32$; IC 95\%: 1,02 - 1,71) y mayor que 34 años (OR=1,39; IC 95\%: 1,12 - 1,72); escolaridad materna inadecuada para la edad (OR=2,11; IC 95\%: 1,22 - 3,65); embarazo múltiple (OR=1,14; IC 95\%: 1,01 - 1,29); cesárea (OR=1,15; IC 95\%: 1,03 - 1,29); peso al nacer menor que 2.500g (OR=4,04; IC 95\%: 3,64 - 4,49); Indice de Apgar en el $5^{\circ}$ minuto de cero a tres $(\mathrm{OR}=1,47 ; \mathrm{IC} 95 \%$ : 1,12 - 1,91) y pre natal inadecuado $(\mathrm{OR}=1,18$; IC 95\%: 1,02 - 1,36). Conclusión: El presente estudio evidenció las consecuencias más inmediatas de la prematuridad para los recién nacidos al revelar su asociación con peores puntajes de Apgar y bajo peso al nacimiento. Mostró como posibles determinantes más distales de prematuridad: edad materna, educación materna inadecuada, gestación múltiple, pre natal inadecuado y realización de cesárea.

\section{DESCRIPTORES}

Nacimiento Prematuro; Factores de Riesgo; Enfermería Maternoinfantil; Atención Prenatal; Estudios de Casos y Controles.

\section{REFERENCES}

1. Silva AMR, Almeida MF, Matsuo T, Soares DA. Fatores de risco para nascimentos pré-termo em Londrina, Paraná, Brasil. Cad Saúde Pública. 2009;25(10):2125-38.

2. World Health Organization. Preterm birth [Internet]. Geneva: WHO, updated Nov 2015 [cited 2015 Dec 12]. Available from: http://www. who.int/mediacentre/factsheets/fs363/en/

3. World Health Organization. WHO (US). Brazil: health profile [Internet]. Geneva: WHO, updated Jan 2015 [cited 2012 Oct 10] Available from: http://www.who.int/gho/countries/bra.pdf

4. Brasil. Ministério da Saúde; Secretaria de Atenção à Saúde, Departamento de Ações Programáticas e Estratégicas. Atenção à saúde do recém-nascido: guia para os profissionais de saúde. Brasília: MS; 2011.

5. Brasil. Ministério da Saúde. DATASUS. Nascidos vivos - Rio Grande do Sul [Internet]. Brasilia; 2012 [citado 2012 out. 10]. Disponível em: http://tabnet.datasus.gov.br/cgi/tabcgi.exe?sinasc/cnv/nvrs.def

6. Barros FC, Victora CG, Matijasevich A, Santos IS, Hosta BL, Silveira ME, et al. Preterm birth, low birth weight, and intrauterine growth restriction in three birth cohorts in Southern Brazil: 1982, 1993 and 2004. Cad Saúde Pública. 2008;24 Supl 3:S390-S8.

7. Porto Alegre. Prefeitura Municipal; Secretaria Municipal de Saúde, Coordenadoria Geral de Vigilância em Saúde. Equipe de Vigilância de Eventos Vitais, Doenças e Agravos não Transmissíveis. Sistema de Informações sobre Nascidos Vivos - SINASC: relatório. Porto Alegre; 2012.

8. Brasil. Ministério da Educação; Secretaria de Educação Básica, Diretoria de Concepções e Orientações Curriculares para a Educação Básica. Jovens de 15 a 17 anos no ensino fundamental: caderno de reflexões. Brasilia; 2011.

9. Gaiva MA, Fujimori E, Sato AP. Pediatric patient classification system: improvement of an instrument. Rev Esc Enferm USP [Internet]. 2014 [cited 2012 Dec 10];48(5):778-86. Available from: http://www.scielo.br/pdf/reeusp/v48n5/0080-6234-reeusp-48-05-787.pdf

10. Victora CG, Huttly SR, Fuchs SC, Olinto MT. The role of conceptual frameworks in epidemiological analysis: a hierarchical approach. Int J Epidemiol. 1997;26(1):224-7.

11. Witt WP, Cheng ER, Wisk LE, Litzelman K, Chatterjee D, Mandell K, et al. Preterm birth in the United States: the impact of stressful life events prior to conception and maternal age. Am J Public Health. 2014;104 Suppl 1:S73-80.

12. Martins MG, Santos GHN, Sousa MS, Costa JEFB, Simões VMF. Associação de gravidez na adolescência e prematuridade. Rev Bras Ginecol Obstet. 2011;33(11):354-60.

13. Newburn-Cook CV, Onyskiw JE. Is older maternal age a risk factor for preterm birth and fetal growth restriction? A systematic review. Health Care Women Int. 2005;26(9):852-75.

14. Auger N, Hansen AV, Mortensen L. Contribution of maternal age to preterm birth rates in Denmark and Quebec, 1981-2008. Am J Public Health. 2013;103(10):e33-8.

15. Assunção PL, Novaes HMD, Alencar GP, Melo ASO, Almeida MF. Fatores associados ao nascimento pré-termo em Campina Grande, Paraíba, Brasil: um estudo caso-controle. Cad Saúde Pública. 2012;28(6):1078-90.

16. Santos NL, Costa MC, Amaral MT, Vieira GO, Bacelar EB, Almeida AH. Gravidez na adolescência: análise de fatores de risco para baixo peso, prematuridade e cesariana. Ciên Saúde Coletiva. 2014;19(3):719-26.

17. Auger N, Abrahamowicz M, Park AL, Wynant W. Extreme maternal education and preterm birth: time-to-event analysis of age and nativitydependent risks. Ann Epidemiol. 2013;23(1):1-6.

18. Auger N, Abrahamowicz M, Wynant W, Lo E. Gestational age-dependent risk factors for preterm birth: associations with maternal education and age early in gestation. Eur J Obst Gynecol Reprod Biol. 2014;176:132-6.

19. Passini R, Cecatti JG, Lajos GJ, Tedesco RP, Nomura ML, Dias TZ, et al. Brazilian multicentre study on preterm birth (EMIP): prevalence and factors associated with spontaneous preterm birth. PLoS One. 2014;9(10):e109069.

20. Melo WA, Carvalho MDB. Análise multivariada dos fatores de risco para prematuridade no sul do Brasil. Rev Eletr Gestão Saúde [Internet]. 2014 [citado 2015 dez. 12];5(2):398-9. Disponível em: http://gestaoesaude.unb.br/index.php/gestaoesaude/article/view/719

21. Fuchs K, Wapner R. Elective cesarean section and induction and their impact on late preterm births. Clin Perinatol. 2006;33(4):793-801.

22. Reddy UM, Zhang J, Sun L, Chen Z, Raju TN, Laughon SK. Neonatal mortality by attempted route of delivery in early preterm birth. Am J Obstet Gynecol. 2012;207(2):117.e1-8.

23. Iliodromiti S, Mackay DF, Smith GCS, Pell JP, Nelson SM. Apgar score and the risk of cause-specifi c infant mortality: a population-based cohort study. Lancet. 2014;384(9956):1749-55. 
24. Catlin EA, Carpenter MW, Brann BS, Mayfield SR, Shaul PW, Goldstein M, et al. The Apgar score revisited: influence of gestational age. J Pediatr. 1986;109(5):865-8.

25. Rades Ê, Bittar RE, Zubaig M. Determinantes diretos do parto prematuro eletivo e os resultados neonatais. Rev Bras Ginecol Obstet. 2004;26(8):655-62.

26. Ferraz TR, ET N. Fatores de risco para baixo peso ao nascer em maternidades públicas: um estudo transversal. Rev Gaúcha Enferm [Internet]. 2011 [citado 2015 dez. 12];32(1):86-92. Disponível em: http://www.scielo.br/pdf/rgenf/v32n1/a11v32n1.pdf

27. Almeida AC, Jesus ACP, Lima PFT, Moura MF, Araújo, Araújo TM. Fatores de risco maternos para prematuridade em uma maternidade pública de Imperatriz-MA. Rev Gaúcha Enferm [Internet]. 2012 [citado 2015 dez. 12];33(2):86-94. Disponível em: http://www.scielo.br/ pdf/rgenf/v33n2/13.pdf

28. Bezerra LC, Oliveira SMJV, Latorre MRDO. Prevalência e fatores associados à prematuridade entre gestantes submetidas à inibição de trabalho de parto prematuro. Rev Bras Saúde Mater Infant. 2006;6(2):223-9.

29. Vasconcelos JDAL, Santos ACC, Batista ALA, Granville-Garcia AF, Santiago LM, Menezes VA. Fatores de risco relacionados à prematuridade ao nascer: um estudo caso-controle. Odonto. 2012;20(40):119-27.

30. Lutenbacher M, Gabbe PT, Karp SM, Dietrich MS, Narrigan D, Carpenter L, et al. Does additional prenatal care in the home improve birth outcomes for women with a prior preterm delivery? A randomized clinical trial. Matern Child Health J. 2014;18(5):1142-54. 